\title{
NON-FORMAL EDUCATION INSTITUTIONS IN THE SYSTEM OF CIVIC BUILDINGS IN UKRAINE
}

\section{POZAFORMALNE INSTYTUCJE EDUKACYJNE W SYSTEMIE BUDYNKÓW OBYWATELSKICH NA UKRAINIE}

DOI: 10.30540/sae-2020-003

\begin{abstract}
The article presents individual positions of the author's research on the integration of non-formal education institutions in the system of civil buildings of Ukraine. The following scientific views on the phenomenon of non-formal education from related industries are analyzed: pedagogy, sociology, psychology, economics and a systematic approach to education as a phenomenon. The prognostic positions of the development of a typological network of non-formal education institutions in connection with the system of public buildings are described. The links are revealed-system objects of a combination of non-formal education institutions with other public buildings. The stages of the study of this problem are briefly described. The proposal on the creation of a universal educational cluster, as a characteristic of non-formal education institutions, is presented, and an example of the formation of the educational block of the center of scientific and technical creativity based on such a cluster is given.
\end{abstract}

Keywords: non-formal education, institutions of non-formal education, a system of civil buildings, typological identity

\section{Streszczenie}

$W$ artykule przedstawiono indywidualne stanowiska badań autora nad integracja pozaformalnych instytucji edukacyjnych z systemem budynków cywilnych Ukrainy. Analizowane sq następujace poglady naukowe na temat zjawiska edukacji pozaformalnej w powiązanych branżach: pedagogika, socjologia, psychologia, ekonomia i systematyczne podejście do edukacji jako zjawiska.

Opisano stanowiska prognostyczne rozwoju typologicznej sieci pozaformalnych placówek oświatowych w powiąaniu z systemem budynków publicznych. Ujawniono powiąania - obiekty systemowe połaczenia pozaformalnych instytucji edukacyjnych z innymi budynkami użyteczności publicznej. Etapy badania tego problemu zostaty krótko opisane. Przedstawiono propozycje utworzenia uniwersalnego klastra edukacyjnegocharakterystycznego dla instytucji edukacji pozaformalnej, oraz podano przykład utworzenia bloku edukacyjnego centrum kreatywności naukowej i technicznej opartej na takim klastrze.

Słowa kluczowe: edukacja pozaformalna, instytucje edukacji pozaformalnej, system budynków cywilnych, tożsamość typologiczna

\section{INTRODUCTION}

According to International Standard Classification of Education, non-formal education is education that is institutionalised, intentional and planned by an education provider. The defining characteristic of nonformal education is that it is an addition, alternative and/or complement to formal education within the process of lifelong learning of individuals. It is often provided in order to guarantee the right of access to education for all. It caters to people of all ages but does not necessarily apply a continuous pathway structure; it may be short in duration and/or low-intensity; and it is typically provided in the form of short courses, workshops or seminars. Non-formal education mostly leads to qualifications that are not recognised as formal or equivalent to formal qualifications by the relevant national or sub-national education authorities or to no qualifications at all. Nevertheless, 
formal, recognised qualifications may be obtained through exclusive participation in specific non-formal education programmes; this often happens when the non-formal programme completes the competencies obtained in another context. Depending on the national context, non-formal education can cover programmes contributing to adult and youth literacy and education for out-of-school children, as well as programmes on life skills, work skills, and social or cultural development. It can include training in a workplace to improve or adapt existing qualifications and skills, training for unemployed or inactive persons, as well as alternative educational pathways to formal education and training in some cases. It can also include learning activities pursued for self-development and, thus, is not necessarily job related [1].

A systematic approach is the direction of the research methodology, which consists of examining the object as an integral set of elements in the totality of relations and relations between them, that is, considering the object as a system. If you look at the history of the development of definitions of the concept of «system», you can see that each of them reveals a new aspect of the content of this concept. In this case, two main groups of definitions are distinguished. One gravitates to a philosophical understanding of the concept of «system». V.N. Sadovsky gives about 40 definitions of the concept of «system», which are most widely used in literature / System (from the Greek. Systema - a whole made up of parts; connection) - this is a set of elements that are in relation and connection with each other, form certain integrity, unity. Another group of definitions is based on the practical use of systemic methodology and tends to develop a general scientific concept of a system. It is widely represented in the international systemic movement (V.G. Ashby, J. Clear, and others). By the definition of L. Bertalanffy: a system is a complex of interacting elements. A Russian researcher O. Averyanov provides the following definition of this concept: "a system is a limited set of interacting elements" [2]. The system of non-formal education institutions is a subsystem of the educational system, which provides the opportunity to conduct educational programs.

Prikhodko V.V. defines the education system as one of the main social institutions, the most important sphere of personality formation, the historically formed nationwide system of educational institutions and governing bodies, which acts in the interests of educating the younger generation, preparing it for independent life and professional activity, as well as satisfying the individual educational needs. It covers pupils of pre-school educational institutions, general educational institutions, professional institutions and students of higher educational establishments; various forms of vocational training, retraining and advanced training of pedagogical workers, extracurricular and educational and cultural and educational institutions [3]. Bykovskaya O.V. notes that the study of educational problems, including extracurricular ones, has in recent years significantly increased the application of system guidelines to the significant changes that are taking place in it. This was facilitated by two factors: the methodological impact of other sciences and the need for practice. The scholar distinguishes the following components of leisure education, which are related both to it and to each other: activity, institutional, organizational, content, methodological, procedural, functional. The author substantiates the claim that extracurricular education (as a powerful component of non-formal education) develops as a dynamic system in the unity of all components, and its development is determined by socio-economic factors and the hierarchy of values of society. At the same time, the relationship of the extracurricular education system with the social environment is open and manifests itself in changes in both the environment and the system as a whole [4].

Pavlik N.P. notes that from the standpoint of the systematic approach as a methodology of cognition, education is seen as an open system that provides the external environment for people who are needed for the functioning of other social systems. The education system is formed by a complex set of pedagogical systems (pre-school system, system of general । secondary education, system of vocational education, system of special secondary and higher education) and subsystems (kindergartens, kindergartens, secondary schools, vocational schools, universities), which in their own queues are composed of lower order subsystems (faculties, departments, academic groups, classes, etc.) [5]. In the context of the current research, the author considers it appropriate to determine the place of nonformal education in the system of scientific pedagogical approaches described by Pavlik N.P. Namely, nonformal education is an open educational subsystem a source for the formation and implementation of the concept of lifelong learning; process, result, system of institutions and institutions aimed at social integration of its subjects, assimilation of systematic knowledge, formation of outlook, development of cognitive capabilities, acquisition of skills (Fig. 1). 


\section{structure}

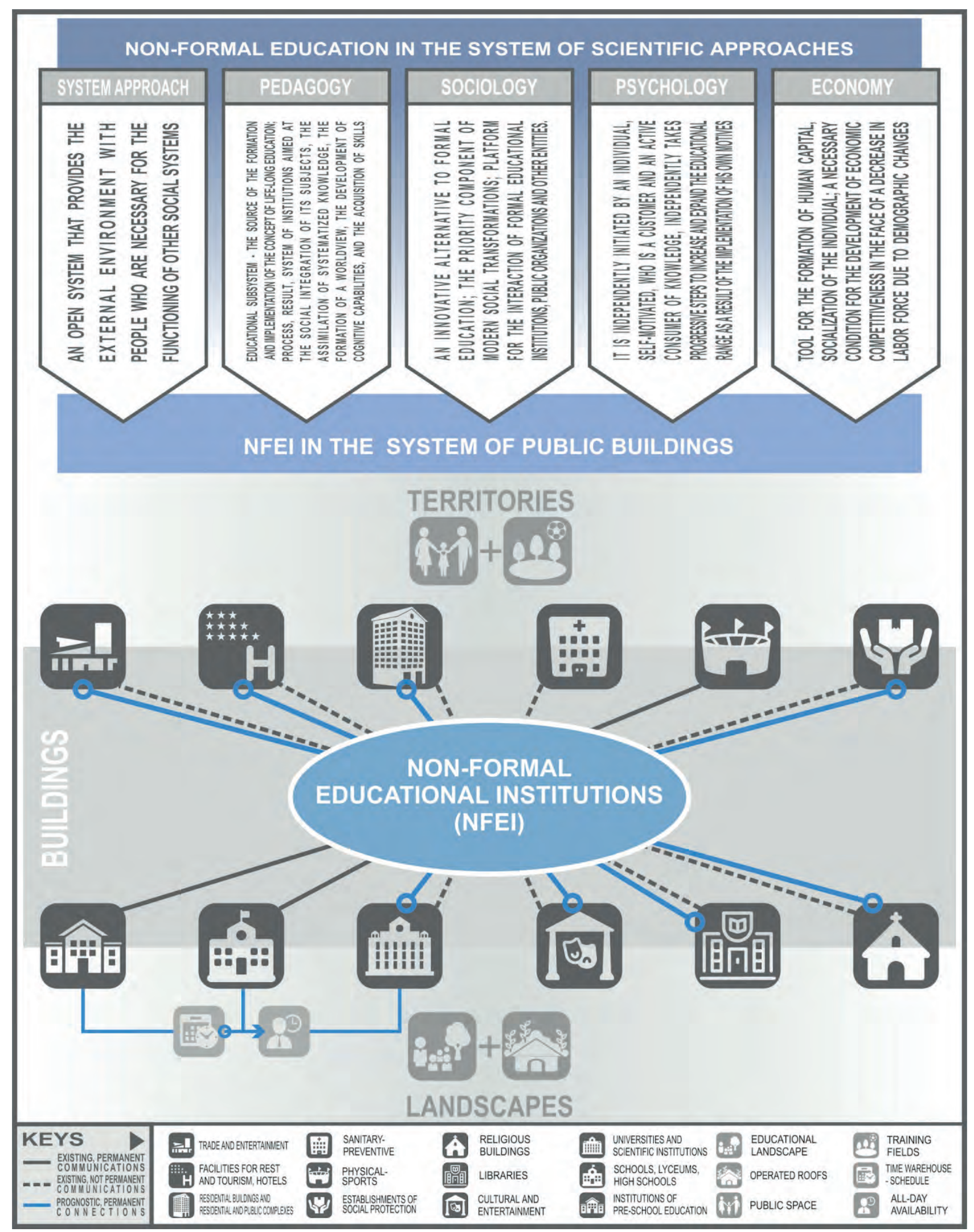

Fig. 1. Non-formal education institutions (NFEI) in the system of civic buildings in Ukraine

Source: author's own research results, research in the related industries [2-10], icons [18]. 
Elagin V.P. and Blagovestov M.O. note that in the sociological field, non-formal education is developing as an innovative alternative to formal education. It is often additional in the form of a grassroots initiative that is decentralized, focused on the needs of the subject and characterized by personality and self-motivation. Non-formal education is a priority component of modern social transformations due to its flexibility to engage in educational activities of various social and age groups (from young people to the age of three). It is a platform for the interaction of formal educational institutions, public organizations and other entities (Fig. 1). Scientists have identified the following trends in the development of non-formal education in Ukraine: the need for legislative recognition of this form of education; increasing the number of state support areas; development of the system of non-formal education on public initiatives. However, it has been found that the change in the methods of providing educational services is connected with the development of information, multimedia technologies, distance learning and so on. In particular, non-formal education, through the use of electronic means, responds most flexibly to the demands of the modern market and naturally fits into the innovative model of development of modern society [6].

Moskalenko L.M., in particular, notes that in the conditions of economic and social mobility of society, as well as its technological growth, it becomes obvious that formal education can no longer meet the diverse educational needs of modern man. It is nonformal education that is further evolving in the face of the global crisis and the need to adapt in an everchanging environment. Today, the development of non-formal education is relevant for many developed countries, in which it is considered as a source of competence of modern man [7].

Tkach T.V. sets out the vision of the phenomenon of non-formal education in terms of psychology. Namely, non-formal education does not provide participants with special certificates, but holds a special place in human life, because it is an activity aimed at gaining practical experience. Therefore, it is referred to as "learning by doing". It is open and accessible to people of all ages, social status and personal development. This principle of education gives a person the opportunity to access education, not by age, but in need. The psychological aspect in organizing nonformal education is that it is independently initiated by the individual who is the customer and the active consumer of knowledge. The motivation behind this activity is that the individual tries not only to become aware of changes that have taken place in a particular environment (professional, social, etc.), but also to become the source of these changes. This suggests that the psychological aspect of involving and joining a person in the system of non-formal education is that the individual is not involuntarily involved in the learning process, but motivated by their own will. They independently take progressive steps to increase and expand the educational range as a result of realizing their own motives, needs, interests, which determines the development of their personality [8].

Economists say that the development of a continuing education system as a prerequisite for the development of competitiveness of the economy in the context of labor force decline due to demographic changes has become the main engine for the formation of a strategy for technical and vocational education and retraining in the leading countries of the world [9]. Economists also draw attention to the growing role of human capital as one of the driving forces for the development of various levels of supplementary education [10].

Lucjan W. Kamionka, notes that in the modern world, architecture has become a discipline that covers a wide range of issues that go beyond the traditionally accepted ability to organize and shape space in realistic and accessible forms for a particular era. Architects of the future must have in-depth interdisciplinary knowledge [11]. That is why this architectural study analyzed various approaches to the concept of "non-formal education" as a system, before starting to create a theoretical model of a building system for non-formal education institutions.

\section{BASIC THEORY}

The basic theory of the functioning of non-formal education institutions (NFEI) in the system of civic buildings is as follows. The author has identified a typological series of civic buildings that are capable of functionally incorporating non-formal education centres into their premises. Such links are indicated in Figure 1. These are shopping and entertainment complexes and multifunctional buildings, residential buildings and housing and public complexes, sanatorium-and-prophylactic institutions, sports and sports facilities, social welfare institutions, places of worship, libraries, buildings of cultural and leisure facilities, and, of course, educational institutions. Predictive theory is based on a powerful trend towards the cooperation of resources and functions.

The study found that for the uniform provision of educational and enlightenment services to different 
age groups of users, it is necessary to provide for appropriate means, which, according to the author, are, first of all, the creation of universal multifunctional educational facilities and methods for combining them with other typological links. Predictably, these can be the following system elements (see Fig. 1):

- NFEI + comprehensive school;

- NFEI + higher education institution;

- NFEI + multifunctional complex;

- NFEI + health and recreation homes and facilities;

- NFEI + fitness, health and sports facilities;

- NFEI + cultural and entertainment, permission of the left and religious institutions;

- NFEI + social welfare institutions;

- NFEI + research institutions;

- NFEI + residential buildings;

- NFEI + institutions of public organizations.

When working on the creation of a threedimensional component, it is necessary to provide for the involvement in the functional scenario and the landscape component by creating educational and recreational landscapes.

\section{RESULTS AND DISCUSSION}

The study of the place of non-formal education institutions (NFEI) in the system of public buildings was divided into several stages:

1. The first step was to determine the development of the historical premises of the formation of institutions similar in function to the object of study.

2. The second stage is the analysis of modern world experience in the design, construction and operation of such establishments.

3. The third stage is a generalization of the current regulatory requirements for the creation of architectural objects having educational and/or enlightening functions.

4. The fourth stage is the analysis of the ability of existing typological links of public buildings in cooperation with non-formal educational institutions of various types.

The first stage found that in their formation the buildings for the implementation of non-formal education did not go through an easy, but interesting development path. From the spontaneous emergence of summer colonies, to the formation of a summer camp system, the design, construction and further operation of which were regulated by the state (USSR experience). Also interesting is the experience of the emergence and development of the architecture of the so-called people's houses, which later developed into the houses of pioneers and schoolchildren, trade unions and workers, which later became centers for the development of children and youth, various clubs and the like. The defining link for the formation of a typological network of non-formal education institutions in Ukraine was the periods of 1917-1930. 1918 is the year of the birth of extracurricular education in Ukraine as a system; in the 20-30s of the 20th century, the system of extracurricular institutions rapidly formed and by 1940 their interaction with the school was established [12].

At the second stage of the study, an analysis was made of the modern experience in the formation of the architecture of non-formal educational institutions, which really strikes with examples. In addition to the formation of monofunctional institutions of additional education, there are very successful objects that combine not only various functions, but also different age categories of users, various methods of forming a three-dimensional component and demonstrate the architecturally sound use of historical buildings and structures that no longer function by appointment for one reason or another. In addition, when considering modern examples of public buildings of foreign experience, a powerful tendency was found to combine the various typological links of public buildings with institutions that provide educational and/or educational services. The author of the article already wrote about some such examples [13-15].

The third stage of the study showed a certain lack of flexibility in the existing regulatory documents on the creation of NFEI in the modern sense. First of all, this concerns the mode of functioning of educational facilities. It is clear that with the rapid growth of public demand for new educational scenarios, including new architectural objects, it is necessary to determine a new algorithm for the formation of NFEI. The author suggested, among other things, to study the formation of universal educational clusters of various capacities and purposes, for the integration of educational centers in public buildings, which are typologically related to other links. Smirnova A.V., for example, was engaged in the typological foundations of the formation of innovative buildings in the urban environment. Among other things, the scientist notes that the modular method of shaping in architecture is one of the most common in foreign practice, often determines the appearance and constructive solution of buildings. The main reason for the growing interest in modular architectural forms is the spread of environmental ideas, the desire for economically viable construction, costs and environmental damage. These qualities (environmental 
friendliness and economy) should be observed not only in the external form of the building but mainly in structural, functional relationships that facilitate the integration of individual modules of an architectural object into the system. The module (from the Latin: Modulus - measure) - the initial value, taken as the basis for calculating the size of buildings or structures, their parts, components and elements, and serves to express multiple ratios of sizes of an architectural object and its parts. As a module, measures are taken of the length of one of the elements of an object; an element of a structure (determined independently of the absolute dimensions) is a size related to the dimensions of the human body. The module can be a complete element or be an integral part of the building. Also, Smirnova A.V. notes that modular design should be applied in all types of buildings: industrial, residential, civic. Currently, it is especially advisable to use them in multifunctional complexes and innovative research and production facilities [16].

In the study of NFEI architecture, it is necessary to investigate the formation of complex and specialized institutions of additional education at the present stage in order to summarize approaches to the design of NFIE. A major aspect of such developments should be the combination of requirements for a new educational process for different age groups of users.

Along with the global trend of combining different functional training zones in a single space, there is a need to create separate educational modules that should organize and isolate the group for the duration of the lesson in accordance with the type of activity. The author suggested the capacity of this cluster -20 people, as optimal (see Fig. 2). The structural step of the supporting elements is $7.5 \mathrm{~m} \mathrm{x} 9 \mathrm{~m}$. According to the optimal natural light exposure of the training room at 6 $\mathrm{m}$, there are places for classes in this area. The structure can be implemented in a monolithic reinforced concrete framework, a metal framework with overlapping of various types (beams, trusses, structures), etc. Creating places for individual lessons, along with group classes and/or putting them into a common communication space, is also one of the trends in the formation of educational centers. The module is designed for different age groups. During the study, the author also proposed a scientific and technical educational module, which is also formed on the basis of a universal educational module (see Figs. 2, 3) [17].

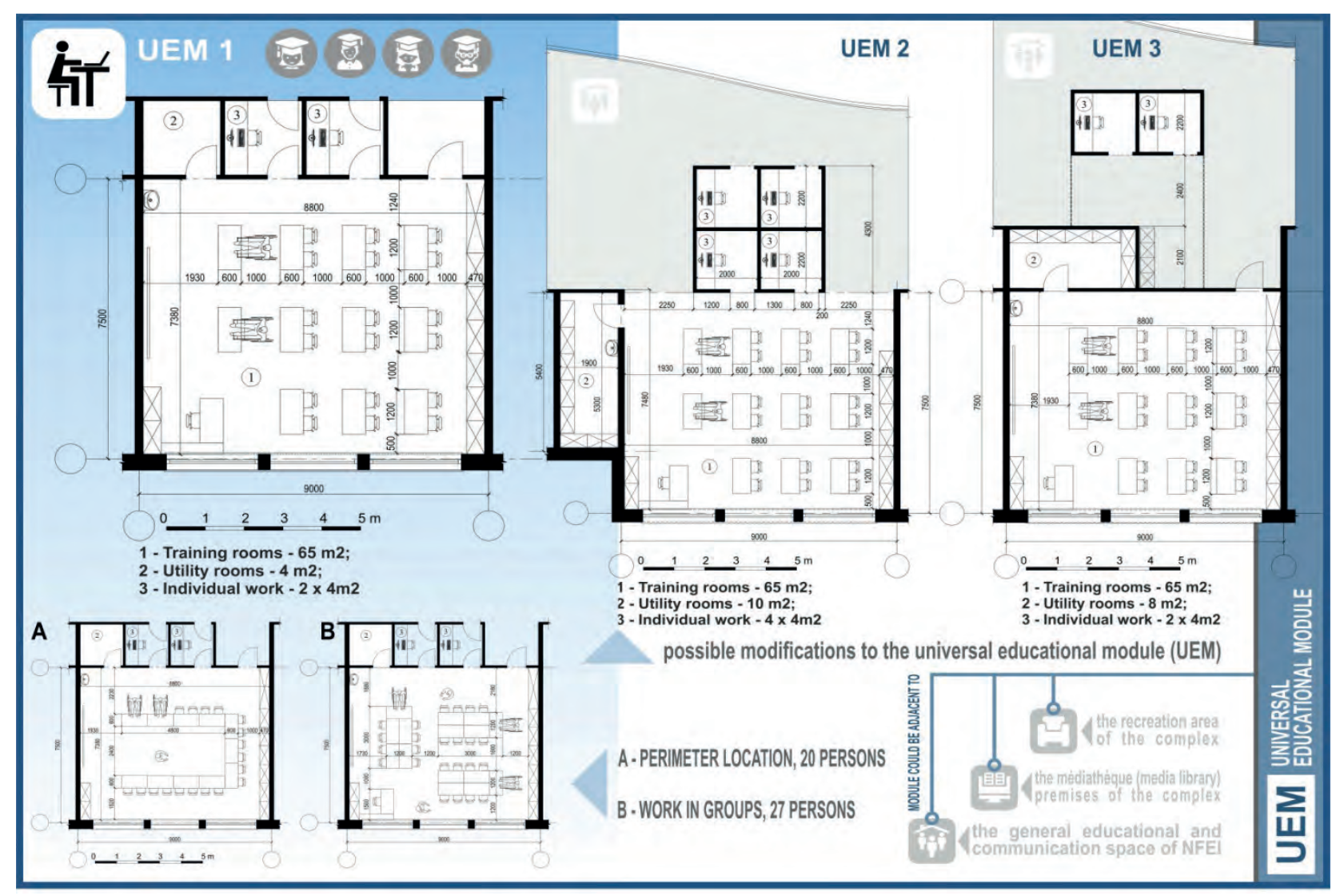

Fig. 2. The proposal for the creation of a universal educational module of NFIE

Source: author's own research results, icons [18]. 
The result of the fourth stage of the study was the following positions. The traditional combination of school buildings with supplementary education institutions in Ukraine takes place in the system of educational buildings to this day. But the problem lies in the fact that for the full functioning of the NFIE, the structural and functional component should be reviewed in order to provide all-day access to the services of additional education to everyone.

Figure 3 presents the proposal of creating a scientific and educational cluster based on a universal educational module (see Fig. 2).

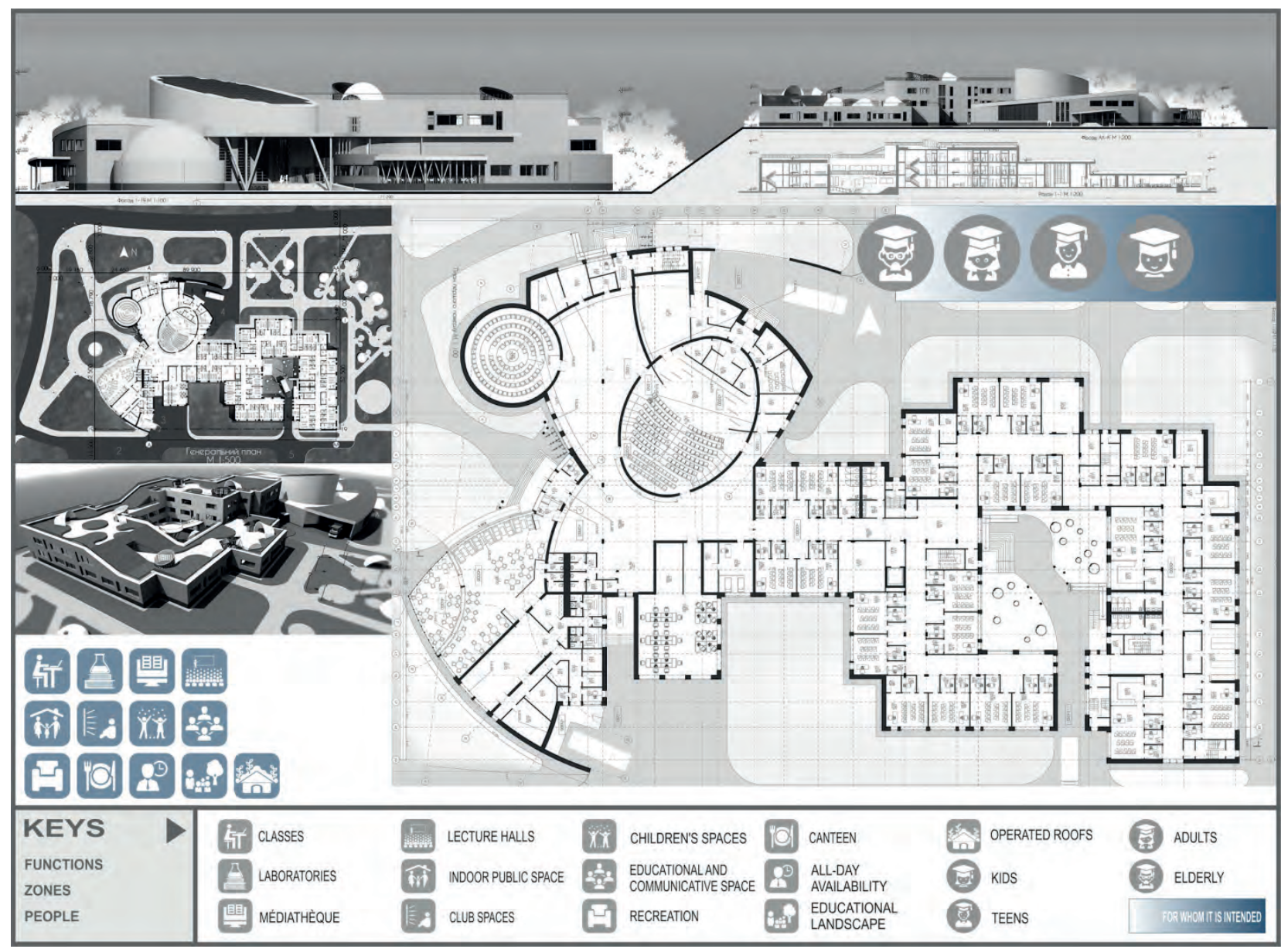

Fig. 3. An example of application of scientific-educational modules in diploma design. Fragment of the diploma diploma project qualification level "master": Features of formation of the center of scientific development of the child. Complied with student ABS-63 Zagorodnya E.A. The Department of Theory of Architecture of KNUCA, Kyiv, 2015. Leader: architect, Ph.D., associate prof. Kravchenko I.L.

Source: the scheme developed by Iryna L. Kravchenko according to master degree project of Zagorodnya E.A., icons [18].

The aim of the graduation project of the qualification level "Master" was an attempt to generalize the requirements for creating a scientific and educational environment, to make it recognizable and comfortable for potential users of different age categories. Thanks to the use of a modular-cluster approach in the design of educational centers of a new generation, it was possible to create an environment that can respond qualitatively to social demand in the field of non-formal education. In the project, such a scientific and educational cluster is connected with a public zone (an act-lecture hall, planetarium premises, a café block) by a common communicative public space of the building. The project is aimed at the practical application of a modular-cluster concept for the development of the architecture of non-formal educational institutions of a research direction. Also, among the main advantages of the project is the improvement of the educational and communicative zone of the educational group of premises by forming recreation centers in a modular architectural and planning component and using the exploited roof for scientific experiments that require outdoor research. Thanks to this decision, the landscape of the center for scientific development performs not only a recreational function, but turns into an educational one, which is also a powerful global trend in the development of architecture of the ZNFO. 


\section{CONCLUSION}

The place of the concept of "non-formal education" in the system of scientific approaches in various branches related to research has been determined. The problem of the formation and development of non-formal education is widely studied in pedagogy, sociology, psychology, economics, and is also the subject of research from the point of view of a systematic approach. Research in the related branches of the phenomenon of "non-formal education" has led to the formation of a view on the creation of the architecture of non-formal education institutions. It was found that an important element in the implementation of non-formal education is, among other things, the creation of an architectural educational space. For the cooperation of other institutions with NFEI, which is the tendency to include such institutions in the system of public buildings, it is proposed to develop a number of universal modules and clusters that can be built-in or attached, and separate institutions of non-formal education of combined functions can be formed from such clusters. The author's suggestions for improving and optimizing the architectural environment for non-formal education institutions are the result of the analysis of numerous scientific works, the historical development of the NFEI architecture, modern experience in the formation of educational institutions of the new time and modern requirements of society for new educational scenarios. So, it is proposed to block the premises of artistic and aesthetic, scientific, technical and other types, in a single group (cluster) with its own entrance group to meet the needs of users throughout the day. In school buildings, the communicative component is also being revised. The space that previously performed the function of connecting groups of rooms now takes on a new meaning and acts as a public educational and recreational space. A tendency towards floor zoning may also be viable.

The idea of creating modules and clusters in architectural practice is not new; many practicing architects and scientists have developed it for various purposes. The purpose of this study is an attempt to generalize the world experience of such exercises and direct it to the improvement of educational institutions, which should provide additional educational services. Based on the fact that the typological identity of public buildings is undergoing significant changes, a universal educational module was proposed - an architectural and planning element that can integrate into the structure of any public building at the design stage, either independently or be an integral part of the educational cluster, which can be recruited from similar elements. The modular-cluster system proposed by the author of the article is only one of the ways that can help create typological links of various capacities and purposes for the integration of nonformal education institutions in the system of civic buildings in Ukraine.

The author sees the following research paths in this context in the search for solutions to architectural and planning schemes of such buildings, different in capacity, location and direction, in the development of proposals for optimizing the educational and recreational space and in the search for methods for incorporating the scientific and educational landscape into the functional structure of the building.

\section{REFERENCES}

[1] Non-formal education. Definition. Source definition ISCED 2011, p. 11-12, items 39, 40. URL: http://uis.unesco.org/ sites/default/files/documents/international-standard-classification-of-education-isced-2011-en.pdf (in Engl.).

[2] Shabanova Y.O.: Systematic Approach in the Higher School, A Textbook for Master's Students in the Higher Education Pedagogy [Systemnyy pidkhid u vyshchyy shkoli: pidruchnyk dlya studentiv mahistratury za spetsial'nistyu «Pedahohika vyshchoyi shkoly»]. Dnipropetrovsk, NMU, 2014, 120 p. (in Ukr.).

[3] Prikhodko V.V, Maliy V.V., Galatska V.L, Mironenko M.A.: Dictionary of Terms and Concepts in Higher Education Pedagogy, A Handbook [Slovnyk terminiv i ponyat' z pedahohiky vyshchoyi shkoly]. Dnepropetrovsk, 2005,181 p. (in Ukr.).

[4] Bykovskaya O.V.: Out-of-school education: theoretical and methodological foundations, monogr. [Pozashkil'na osvita: teoretychni ta metodychni osnovy]. Kiev, EPC ALCON, 2008, 336 pp. (in Ukr.).

[5] Pavlik N.P.: Non-formal education in the education system of Ukraine [Neformal'na osvita u systemi osvity Ukrayiny]. ISSN Online: 2312-5829. Educational discourse. 2016, No. 2 (14), pp. 27-37 (in Ukr.).

[6] Yelagin V.P., Blagovestov M.O.: Development specifics and trends in the system of non-formal education in Ukraine [Osoblyvosti ta tendentsiyi rozvytku systemy neformal'noyi osvity v Ukrayini.]. State building - № 1/2019. An electronic scientific publication of the Kharkiv Regional Institute of Public Administration of the National Academy of Public Administration under the President of Ukraine. ISSN 1992-2337. doi: 10.342 / db.19.01.12 (in Ukr.).

[7] Moskalenko L.M.: Trends in the development of non-formal education in Ukraine (based on a survey) [Tendentsiyi rozvytku neformal'noyi osvity v Ukrayini (za rezul'tatamy sotsiolohichnoho doslidzhennya)]. VISNYK LVIV. UNIV. Sociology Series. 2018. Issue 12, pp. 212-220, DOI: http://dx.doi.org/10.30970/vso.2018.12.12 (in Ukr.). 
[8] Tkach T.V.: Personality development by means of non-formal education. Actual problems of psychology [Rozvytok osobystosti zasoby neformal'noyi osvity. Aktual'ni problemy psykholohiyi]. Collection of scientific works of the Institute of Psychology named after G.S. Kostyuk of the National Academy of Pedagogical Sciences of Ukraine. T.7, Issue 15, 2008. ISSN 2072-4772, pp. 287-291 (in Ukr.).

[9] Polushkina E.A., Krasnova G.A.: The development of the continuing education system of the Netherlands: status and prospects [Razvitiye sistemy nepreryvnogo obrazovaniya Niderlandov: sostoyaniye i perspektivy]. Bulletin of the Peoples' Friendship University of Russia, Informatization of Education series, 2014, No. 4, pp. $92-99$ (in Rus.).

[10] Smirnov V.: Lifelong learning: from the 1920s to the present [Navchannya protyahom zhyttya: vid 1920-kh do s'ohodennya]. Psychological and pedagogical problems of rural school. 2012, No. 43 (2), pp. 342-348. URL: http: // nbuv.gov.ua/UJRN/ (in Ukr.).

[11] Kamionka L.: Creative and coordination attributes in architectural education and in the way of profession for the future. Nacionalnowo Uniwesitetu Lwiwska Politechnika Seria: Architektura. ISSN 2523-4757, Nr 895.2018. Lwów, pp. 49-53 (in Ukr.).

[12] Rusova S.F.: Selected Pedagogical Works [Vybrani pedahohichni tvory], preface Editor O.B. Proskura. Kyiv: Osvita, 1996, 303 p. (in Ukr.).

[13] Kravchenko I.L., Khmel M.: Ways of integration of scientific and technical profile specialized premises into the structure of a comprehensive school. SPACE\&FORM, Szczecin 2019, No 38, pp. 47-58, e-ISSN 2391-7725, ISSN 1895-3247, DOI: 10.21005/pif.2019.38.B-04 (in Engl.).

[14] Kravchenko I.L.: External and internal factors of influence on development of architecture of non-formal education establishments. STRUCTURE AND ENVIRONMENT, Kielce 2019, No. 3/2019, Vol. 11, pp. 177-190, PL ISSN 2081-1500, DOI: 10.30540/sae-2019-013.

[15] Kravchenko I.L.: Ways of formation of architecture of education 's non-formal institutions in modern conditions in Ukraine. STRUCTURE AND ENVIRONMENT, Kielce 2019, No. 2/2019, Vol. 11, pp. 119-125, PL ISSN 20811500. DOI: 10.30540/sae-2019-009 (in Engl.).

[16] Smirnova O.V.: Typological foundations of the formation of innovative buildings in the urban environment, monograph [Tipologicheskiye osnovy formirovaniya innovatsionnykh zdaniy v gorodskoy srede, monografiya]. O.M. Beketov National University of Urban Economy in Kharkiv, Kharkov: KNUUE them. A.N. Beketova, 2018, 189 p., ISBN 978-966-695-438-4 (in Rus.).

[17] Kravchenko I.L., Zagorodnaya E.A.: Modular design of classes and laboratories of an out-of-school educational institution of a scientific direction [Modul'ne proektuvannya klasiv ta laboratoriy pozashkil'noho navchal'noho zakladu naukovoho spryamuvannya]. Modern problems of architecture and urban planning. Scientific and technical collection. Issue No. 42. Kyiv KNUCA 2016, pp. 289-294 (in Ukr.).

[18] Icons. URL: https://www.svgrepo.com/.

\section{Acknowledgments:}

The work was financed by Kiev National University of Construction and Architecture, Architectural faculty Department of the Architectural Theory 31, Povitroflotskyy prosp., 03680, Kyiv, Ukraine

\section{Podziękowania:}

Praca byla finansowana przez Kijowski Narodowy Uniwersytet Budownictwa $i$ Architektury, Wydzial Architektury Katedra Teorii Architektury 31, Povitroflotskyy prosp., 03680, Kijów, Ukraina 